\title{
Bringing Phenomenology Down to Earth: Passivity, Development, and Merleau- Ponty's Transformation of Philosophy
}

David Morris, Department of Philosophy, Concordia University, David.Morris@concordia.ca concordia.academia.edu/DavidMorris

Submitted version. Forthcoming in Chiasmi International: Trilingual Studies Concerning Merleau-Ponty's Thought 16.

\begin{abstract}
I suggest how Merleau-Pontian sense hinges on an ontology in which passivity and what I call "development" are fundamental. This means, though, that the possibility of philosophy cannot be guaranteed in advance: philosophy is a joint operation of philosophers and being, and is radically contingent on a pre-philosophical field. Merleau-Ponty thus transforms philosophy, revealing a philosophy of tomorrow: a new way of doing philosophy that, because it is grounded in pre-reflective contingency, has to wait to describe its beginnings, and so has to keep studying its beginnings tomorrow. This does not destroy Husserl's project of a transcendental philosophy, it just accepts that the transcendental conditions of philosophy cannot be constituted or even revealed via wholly active or autonomous reflection. MerleauPonty thus brings phenomenology down to earth by expanding it into a phenomenology of life and earth that describes the concrete beginnings of phenomena and phenomenology.
\end{abstract}

"The perceived world is the always presupposed foundation of all rationality, all value and all existence. This sort of thesis does not destroy either rationality or the absolute. It only seeks to bring them down to earth" — "The Primacy of Perception and Its Philosophical Consequences"1

"We cannot have truth without risks. If we begin our search for truth with an eye for conclusions, there is no more philosophy. The philosopher does not seek shortcuts; he goes all the way." — "Bergson in the Making",

From the Structure of Behaviour onward, sense - meaning as engendered within being, and one of Merleau-Ponty's greatest discoveries ${ }^{3}$ - is key to Merleau-Ponty's philosophy. Indeed, for Merleau-Ponty, sense is the transcendental condition of philosophy. In this paper I suggest how sense hinges on an ontology in which passivity and what I call "development" are fundamental. This means, though, that the possibility of philosophy cannot be guaranteed in advance: philosophy is a joint operation of philosophers and being, and is radically contingent on a pre-philosophical field that enables philosophy in the first place. Merleau-Ponty thus transforms philosophy, revealing a philosophy of tomorrow: a new way of doing philosophy that, because it is grounded in pre-reflective contingency, has to wait to describe its beginnings, and so has to keep studying its beginnings tomorrow. This does not destroy Husserl's project of a transcendental philosophy grounded in unsurpassable conditions that are autonomous from and irreducible to the terms of any discipline prior to philosophy (e.g., the natural sciences). It just accepts that these conditions cannot be constituted or even revealed via wholly active or autonomous reflection. Merleau-Ponty thus brings phenomenology down to earth: phenomenology must expand into a phenomenology of life and earth that describes the concrete beginnings of phenomena and phenomenology.

I first contextualize my overall point by showing how it springs from MerleauPonty's continual reflection on philosophical beginnings. I then study sense, to show how the phenomenon of sense entails my points about ontology, passivity and development. Finally I suggest how this transforms philosophy. My aim is programmatic: there is not 
enough room for an exhaustive textual exposition, so, for this issue on "Merleau-Ponty Tomorrow," I synthesize themes of his philosophy to offer something new.

\section{1) The Radical Contingency of Philosophical Beginnings}

Merleau-Ponty's philosophy, as with other enduring philosophical work, is notable not just for its results, but for its continual engagement with the question of what philosophy is in the first place. This question is explicit in many of Merleau-Ponty's works, from his Éloge de la philosophie, to "The Philosopher and His Shadow," to Husserl at the Limits of Phenomenology. But the question also fundamentally informs his major works, The Structure of Behaviour (SB, 1942), Phenomenology of Perception (PhP, 1945), and The Visible and the Invisible (VI, 1964), which first of all seek to grasp how we, as reflecting philosophers, relate to the things that we perceive, cognize and conceptualize. For Merleau-Ponty this entails re-envisioning philosophy itself as beginning from within its concrete place amidst things, versus leaping to or springing from a beginning in a ready made "view from above." Hence his ongoing quest for radically empirical methods that embed philosophical beginnings in being itself: Structure's critique of behaviour; Phenomenology's radical reflection; hyper-reflection in The Visible and the Invisible.

This radically empirical commitment to finding both questions and answers beginning within being - to the primacy of perception and "perceptual faith" — entails sense. If there were no meaning, if nothing mattered, then there would be no philosophy, there would be nothing definite to ask questions about - there would not even be the possibility of Cartesian doubt. But if this meaning did not arise within being itself, then our questions and answers could be split from being - there might only be Cartesian doubt. (For Merleau-Ponty, such a self-contained doubt, which would confront being from the outside, is absurd and self-contradictory: since it admits no outside standard, it has no real thing to doubt and admits no real answer.) This tension between "not even doubt" and "only doubt," between being not mattering, and doubt not really mattering, is perhaps the ultimate matrix of all of Merleau-Ponty's other dialectical moves (between empiricism and intellectualism, passivity and activity, and so on).

The transcendental condition of philosophy, then, is sense: being itself mattering in determinate ways that can both motivate and answer our philosophical questions. For philosophy, then, being has to matter - but if being only mattered according to what we already think about it, it would not matter in a way that enabled real doubt and its real resolution. Philosophy is radically contingent on being and nature (visible being) already mattering their own way. This radical contingency is the ultimate topic and topos of philosophy. If we follow Merleau-Ponty all the way to the beginnings of philosophy, we find there is no shortcut even to that beginning. (Descartes's fundamental error is seeking such a shortcut.) Each effort of beginning philosophy reveals philosophy as responsible to and risking a kind of irreducible contingency. This is why phenomenology must expand into a phenomenology of life, earth and a phenomenology of phenomenology, an empirical study of how phenomenology comes to be. As Merleau-Ponty puts it, "Precisely in order to accomplish its will for radicalism, [philosophy] would have to take as its theme the umbilical bond that binds it always to Being, the inalienable horizon with which it is already and henceforth circumvented, the primary initiation which it tries in vain to go back on." (VI 144) ${ }^{4}$ Grasping why this so requires further study of sense as the 
transcendental condition of philosophy, starting with a brief review and illustration of sense.

\section{2) Sense as Meaning Immanent in Being}

Sense is the concept of meaning not as a self-contained idea, representation, or semantic atom (as in classic idealism or current cognitivist or representationalist views), but as inherently leaning upon and arising out of broader situations (as in a consistent version of current enactive or embedded views). Merleau-Ponty's concept draws on multiple connotations of the French word "sens," namely: meaning; direction and orientation, as in a street that is one way, sens unique; and also sense and sensing, as in encountering something sensually. Sense is what's at stake and manifest in structures of behaviour in $S B$. The rootedness of sense in the lived body is a central discovery in $P h P$. Combining results of $S B$ and $P h P$, sense designates meaning as arising in the movements of bodies or other natural systems that operate in ways affected by or responsive to their own directive momentum and context, systems oriented by their own fit with and divergence from their own dynamically shaped norms. To flesh this out in a way that fits with bringing phenomenology down to earth, I elucidate sense in two steps, via Francisco Varela's (1991) analysis of a bacterium moving up glucose gradients. ${ }^{5}$

The first step is showing how meaning is manifest in the bacterial scenario. Varela argues that the bacterium manifests cognitive behaviour: it cognizes distal glucose as food. In my view, this behaviour counts as meaningful in virtue of the bacterium orienting to material as food to be ingested, and not as poison to be avoided, or non-food to not be ingested. This behavioural "and not" is key to meaning. It shows that the bacterium relates to something as something according to a standard. More, this standard (for what counts as food) stands over and above immediate material givens: there could be other standards (for another organism glucose could be poison). We observers can therefore say the bacterium's behaviour interprets its surround according to its own standard, correctly or incorrectly (e.g., it could ingest molecules, as food, that are in fact poison).

Crucially, though, interpretation is not just going on for us observers, it is also implicit and at stake in bacterial living itself. This is because it makes a difference to and in its living that the bacterium relates to glucose as food and not as poison or non-food. The "and not" is at stake for the bacterium too. The material construction of a magnet or machine imposes a standard that drives its differential behaviour. But a bacterium is affected by living in accord with its standard or not. It is more than a system driven by a standards: it is implicitly oriented to and by that standard itself, to living by that standard and not another. The point here is subtle. The bacterium is not just affected by exterior things it encounters, it is also self-related, interiorly affected by how it behaves in encountering those things. ${ }^{6}$ For us, such self-affection is explicit: I encounter something as poison in feeling nausea, an affect oriented to me, not the thing. But in this self-affect I encounter myself as a being with food standards. We need not suppose the bacterium 'feels' anything at all. We need merely observe that in encountering things it manifests an affective and self-affecting relation: it does not just behave as oriented by things, but as oriented to its own standards (as if a magnet were not merely oriented to magnetic 
material, but to its own orientedness). The bacterium thus enacts, maintains, and implicitly encounters its own standards. ${ }^{7}$

To put this another way, as living, a bacterium is an open system that gathers and dissipates energy. In dissipating energy to move toward glucose, it is not dissipating energy in other ways. The bacterium's very activity as living thus involves and implies what it is not doing - and what it is not doing (not eating poison) registers as a selfaffected difference within it. In this way we can see the "and not" of meaning at work in the bacterium. ${ }^{8}$ (If we deny it is affected or that its living matters to it, then my argument fails. But Hans Jonas (1966), Renaud Barbaras (1999, 2003), Evan Thompson (2007), and others have good arguments against doing so - and doing so entails begging the question of meaning, by denying that anything matters. This may be necessary for a certain kind of science, but it is self-contradictory and indefensible if you want to do transcendental philosophy or say how science itself matters.)

We can thus say that meaning is manifest in the phenomenon of the bacterium orienting to $\mathrm{X}$ as $\mathrm{F}$ and not as $\mathrm{P}$. In the bacterium we glimpse the germ of the joke in which Sartre tells the waiter he'll have a cup of coffee with no cream, and the waiter responds, "Sorry, we're out of cream, how about with no milk?" In both cases a standard is at work over and above what is immediately and positively given, in virtue of which $\mathrm{X}$ counts as $\mathrm{F}$ and not $\mathrm{P}$, or as not-M and not not-C. In virtue of this standard, there is meaning. (The joke is that Sartre's standard assigns meaning to non-existent things, négatités.)

The second step shows that the standard of meaning is engendered within this phenomenon itself - that this meaning is sense. Varela shows how the and not and standard of meaning is engendered right in bacterial movement. The bacterium deploys its energy in relation it to its own past and its surround (another respect in which selfaffection is key). When current environmental nutrient levels diverge below levels in the recent past, the bacterium starts tumbling around, instead of moving straight ahead. This tumbling stops when the bacterium tumbles into higher nutrient densities. Overall, given the way glucose diffuses, this means that bacterial movement tends to be oriented toward distal concentrations of glucose. The bacterium's meaningful act of orienting to the distant glucose as food thus arises via joint movement of the bacterium and the environment: the meaning is not 'on board' the bacterium, but leans and waits upon the environment in which it arises. But this joint movement is rooted in the bacterium's own living and evolution in a way that we do not find in the magnet or machine.

The key conceptual point here is that in contrast to (e.g.) Sartrean meaning, the standard of Merleau-Pontian sense: 1) emerges within the domain in which things are sensed as meaningful; and 2) this standard is not given in advance of but emerges in sense-making activity, on various timescales, from evolution to this-here organism moving around.

\section{3) Sense as Immanent and Pre-Reflective: A 'Classic' Transcendental Argument}

This immanence and non-givenness of sense standards is what transforms transcendental philosophy. To see how, let us consider another case of sense. Our left and right hands are what Kant called incongruent counterparts: they have the 'same shape', yet do not fit together when we place them atop one another with both palms facing down. Geometers 
say that left and right hands have a different sense (a usage that fits with MerleauPonty's). Kant was fascinated by geometrical sense, precisely because it escaped a priori determination. Imagine an isolate human $3 \mathrm{~d}$ hand popping into existence in empty space. Without any further context, reason can grasp that it would have an incongruent counterpart, that there is a difference between what we would call left and right hand figures, such that the isolate hand has a unique sense. Yet, absent further context, reason cannot specify what determinate sense it has, whether it is what we on Earth would call a left hand, or a right hand. ${ }^{9}$ This requires a further context, direction, etc. Determining the sense of left, not right, entails being embedded within and traversing a broader situation.

As Onora O'Neill argues (2011), for Kant this issue of left and right leads to the insight that thinking itself ultimately entails orientation within a broader context. Put otherwise, meaningful difference, concepts, and thence philosophy ultimately entail norms that issue from broader contexts that cannot themselves already be constituted as determinately meaningful by reason or philosophical reflection alone. This sketches something like a transcendental argument that the condition of meaning is pre-reflective, that sense is fundamental to thinking. Philosophy then, cannot begin with, e.g., abstract Sartrean negation (or Bergsonian intuition above the turn of experience).

But notice the method of this argument: it asks us to exercise our imagination to abstract from life and concrete situations, and then gets us to notice that we end up referring to differences that our thinking cannot itself constitute. This method of reductio ad absurdum cuts loose from experience precisely to ground it. For Merleau-Ponty, even if it ends up correcting a misconception, in beginning by cutting free of the empirical, via our geometrical imagination, it could end up correcting a misconceived misconception, or misconstruing or missing something about the real beginning points of philosophy.

In contrast, $V I$ is shaped from the start as a dialectical study of the very method of beginning philosophical interrogation, challenging both Sartrean negation and Bergsonian intuition as wrongly attempting to begin philosophy from above experience. In doing so, VI seeks a reductio that is not constrained by the negative goal of avoiding absurdity, but by the positive attempt to find the beginning of philosophy manifest in the being of philosophical activity itself.

The clue here is sense. If philosophy is possible, there must be a dimension of sense in the very appearing of being, and thence in our very access to being from within being, in the activity of philosophy. (This beginning is at once the exact opposite of Descartes's doubt, and also its fulfillment: not an "I doubt," but an "it makes sense.")

Methodologically, then, for Merleau-Ponty returning to the beginnings of philosophy would entail describing, from within our very access to being, how sense is ontologically

and structurally endemic to the very phenomenon of a phenomenon in the first place. ${ }^{10}$ This means describing how being can be manifest as determinate.

\section{4) The Ontology of Sense: Passivity}

Being is determinate. Being is not an undifferentiated void, it is thus and so, different here vs. there. If this were not the case, sense and philosophical questioning would be impossible. How is that being is determinate? What is the ontological structure of determinateness? ${ }^{11}$ Here we must grapple with some difficult points. 
Crucially, encountering being as determinate entails encountering an ontological difference between: being and determinate being. ${ }^{12}$ This difference is at stake in encountering $\mathrm{X}$ as $\mathrm{F}$ and not $\mathrm{P}$. Consider Kant's problem of the hand that pops into being. Yes, the hand $i s$. And it is either what we would call left- or right- handed. But absent orienting standards we cannot, e.g., determine that it is a left hand and not a right hand. Further, without orienting standards, it cannot determinately be a left and not right hand. ${ }^{13}$ The determinate being of the hand is not immediately given in the hand itself. We might put it this way: absent standards, we can grasp that it is, but not what it is, with respect to its determinate whatness. ${ }^{14}$ The whatness of something, its determinate being, is thus different than thatness, mere being. This difference between being and determinate being is central to the very phenomenon of meaning: it is what leaves the latitude for the as and the and not of meaning, room for this-here thing to be determinate as food and not poison.

It is also what leaves latitude for their being philosophy and philosophical questioning in the first place. The difference between being and determinate being is thus central to philosophy. Sartre knows this. To account for négatités (e.g., experiencing black coffee as lacking cream, vs. lacking milk) he distinguishes between: being as a plenum void of all difference; and a nothingness that renders being determinate as this and not that. For Sartre, determinate being thus comes to being from the outside: being itself is nothing determinate whatsoever. Or, consider Socrates's argument in Phaedo that there is nothing in sticks themselves that could vest them with the determination "equal." Encountering that determinateness takes a further idea that is incommensurate with the raw "that it is" of this here stuff. In both the Sartrean and Socratic cases, determinate being entails a reality-appearance distinction: being appearing as determinately this or that entails a reality of ideas or consciousness beyond the being of appearance.

The difference between being and determinate being is key to philosophy. But it also leads to confusions. Articulating these with clarity is tricky and requires more room than I have. To give an example, though, recall that encountering meaningful, determinate being entails encountering a difference between being and determinate being - this difference is what opens room for questions and interpretation. This difference can lead to a conceptual framework in which: first, the being of things (of the coffee or sticks) is emptied of all inherent determinacy (to leave ontological latitude for it to be determined as this and not that); yet, second, some mediating term must account for this determinacy, and to do this, it must already possess the determinacy that it will assign, independent of the emptied being to which it will assign determinacy (as is the case with Socratic ideas, or Sartrean nothingness ${ }^{15}$ ). In my view, this ends up confusing being and determinate being: we encounter a determinateness in experienced things, notice that it is variable, indeterminate, and therefore try to ground it not in these things themselves but something different, in some other already given being. But to do that, we have pack determinateness into that other being. So we model being itself on the determinateness it is supposed to account for, we confuse being with a determinate being, or engage in more subtle variants of this confusion. It is as if we presuppose that determinateness could not be local to things (as if things cannot pull this off - a legacy of Cartesian skepticism), that things already had to be either wholly determinate or not, that there is no room for determinateness to eventuate in being and beings. So we erroneously think that the determinate character of things must be rooted in something bigger and already 
determinate (e.g., being as a whole, space, time, law, ideas, freedom). (This ontological error echoes a key epistemological problem of $P h P$, viz. how a thing could call upon our perception or cognition to determine it is this and not that, if it were not already determinate - with Merleau-Ponty arguing that ambiguous determinacy is key.)

In my view a key achievement of VI, in conjunction with Merleau-Ponty's later work on the world of sense, nature, institution and passivity, is to present an ontology of phenomena that accounts for the determinacy of being in an innovative way that escapes this confusion and error. Merleau-Ponty accepts that knowledge, perception and philosophy entail distinguishing between being and determinate being. What he objects to is the thought that this distinction is based in a dualism between things appearing and some reality beyond them. The appearance-reality distinction is within things and being itself. This is why he can say that meaning is a sense within things.

Here we have to work through some challenging points central to VI. To say there is no reality appearance dualism is to say that: Being shows up as, and in, its own determinate appearance. What determinately appears is being itself. That is: appearance is not a visible veil hiding an invisible being that never could show up. Appearance is not the appearance of something else, something hidden. Appearance is the appearance of being itself. Being has no independent reality outside of its appearing. And yet: there is a difference between the thatness and whatness of something. To be determinate, being must show itself as being determinately what it is, and this entails a standard that is more than that which is given here and now. On classic views, this standard is, e.g., a Platonist idea that can never show up. Yet Merleau-Ponty undermines the ontological dualism between visible appearance and an invisible reality behind the scenes. There may be an ontological difference between being and determinate being, but this does not mean that being and determinate being are two disjoint entities. Rather, they are two inflections of one being, or better, their difference is a sign that being inflects itself with its own endogenous standards. ${ }^{16}$

So we need a standard of determinacy that is something more than what is given here and now, that could not therefore be directly visible in the here and now-but must nonetheless show up in that which appears. In VI Merleau-Ponty grasps this paradoxical standard by conceptualizing something invisible right there in the visible and nowhere else, an invisible that is of the visible.

My insight is that the key to grasping this ontologically paradoxical standard is another ontological term crucial to Merleau-Ponty's later philosophy: passivity. Determinate being entails a kind of ontological passivity that is not reducible to a deficit in activity. ${ }^{17}$ There is a sort of positive weakness in being, a negative in being, such that, if being is to be what it is, it cannot show up all at once. Thus, in its very showing, being shows...that it cannot show up as such, as being once and for all. But it is right in being's showing up as passivity that it shows this not showing up: it's in, and only in, the visible that the invisible shows up. Being thus deepens into the standard against which it operates as showing up as determinate. There is a sort of echo here between: being as passively operating in relation to itself; and the bacterium as operating affectively in relation to itself. In sense-making, the bacterium relates to itself, to its own past, and to its own surround and displacements. So too, being as a whole cannot be an immediate plenum, or an absolute, divine self-coincidence; rather it is what it is via self-inflection or non-coincidence. ${ }^{18}$ 
In the form of a transcendental argument, the point here is that the condition of possibility of determinate being and thence meaning is being doubling onto itself. Being at once gives itself determinately and gives the standard in virtue of which it is determinate. Classical ontologies would cash out this twofold givenness via a dualism of appearance and reality. Merleau-Ponty instead conceives a kind of ontological passivity, through which alone, in being there, being is not all there and is thereby something more, a standard. Instead of two parallel kinds of givenness, reality and appearance, we have a givenness that is less than given and so diverges from itself to be its own standard, in the way that a throw that is off the mark itself manifests its divergence from its target. ${ }^{19}$ Merleau-Ponty often conceptualizes this via the image of being as 'hollow,' creux. We will see that this transforms the very idea of transcendental conditions.

\section{5) Development and Being as Radical Contingency}

A natural question at this point is to ask: How is it that being is already prepared with this sort of passivity that can open the latitude for engendering sense? The key is grasping how this is precisely the wrong question to ask.

The question of the origin of sense is begged if the answer is: because some foundation of sense is already given. For this would amount to saying: sense is not really sense, meaning doesn't really arise in being by leaning or waiting upon broader situations or processes, meaning has its condition in something already and fully given. This would mean that the phenomenon of sense is an illusion. And it reverts to a reality-appearance distinction, in which, if you are a rationalist, sense is an illusion because meaning is real only in an already given realm that is not hostage to appearances, in the way that sense is; or, if you are an empiricist or nominalist, meaning is not really real at all, but a mere illusory appearance. Either way, you betray phenomenology's effort to take the phenomena seriously. For sense to be sense, it cannot quite have an already and fully given origin.

It is precisely in trying to avoid such conceptual problems, and taking phenomena of learning and language seriously that the concept of what I call development becomes central to a Merleau-Pontian philosophy, even though he doesn't himself use that word as a central term of his vocabulary, or in quite the way I do.

That is, my thought is that Merleau-Ponty's answer to the question "Where does sense come from?" is that sense develops. According to my conception, this is to say sense has its condition of possibility in an antecedent sense from which alone it develops. Yet, crucially, the antecedent sense does not yet contain or specify in any definite way the new sense that might turn out to have developed from it. Development, as I define it here, can always in principle generate something new, even if it does not in fact always do so. If development could not generate something new, if it was merely the unfolding of already specified programs, then the way in which sense leans upon something broader would be precisely undermined. Development, we could say, plays out the radical contingency of sense as always leaning and waiting upon a broader situation and process.

This concept of development challenges traditional divisions between an a priori that must already be given if there is ever to be meaning, and an a posteriori of senseless data that are already given. This is because development is a process that in effect engenders new a prioris. Phenomena of perceptual learning precisely drive Merleau- 
Ponty to realize that perceptual processes engender their own a prioris, by reworking a sense that is already endogenous to our perceptual embeddedness in a situation, as in his discussion of the child learning to see new colours ( $P h P$ 36-39).

What is key here is that development does not move from: no-sense at all, to sense; but neither does development arrive at determinate sense by unfolding programs that must already have been given, even if they were not yet deployed. Rather, development moves from one sort of sense to a different sort of sense, and it does so only by engaging and moving through a sense that was already there. Development is kin to stumbling around on deck, as the only way to gain your sea legs - and that means there's no guarantee that you will get your sea legs, or that something else might not happen instead. There is a sort of creative generativity endogenous to development, and it hinges on ways of sensing environments and situations. This sort of creative generativity is of course key to primary expression. My concept of development basically says: for there to be sense and expression, expression has to go all the way down (cf. Landes 2013; Fóti 2013).

This means that being cannot stand as an already given foundation of philosophy, in some sort of abstractly transcendental sense. If being enables philosophy, it is because being has contingently turned out to grant the concrete place from which philosophy finds itself beginning. ${ }^{20}$

Notice how this transforms transcendental conditions: we have a transcendental argument that if philosophy is possible, certain irreducible conditions must obtain. But paradoxically, the argument is that these conditions only work by not guaranteeing philosophy in advance. Such a guarantee would require reference to a standard outside of or in advance of the being that philosophy actually interrogates, and if philosophical interrogation operates via such a standard then it is, for Merleau-Ponty, philosophy gone awry, philosophy that is not truly about being, but something else. (Religion may contemplate such a given standard, but it is off limits to radically empirical phenomenology.) There is no transcendental condition of philosophy given in advance, and this is why philosophy requires perceptual faith, and is always of tomorrow. Derrida's analysis of the transcendental conditions of Husserlian sense similarly shows how these undo transcendental conditionality - but Merleau-Ponty's analysis proceeds in and through being, in a manner different than Derrida, that brings phenomenology down to earth.

\section{6) Bringing Phenomenology Down to Earth}

I have argued that what I call the developmental character of being turns out to be a transcendental condition of sense. This means that sense is radically contingent, vs. something that can be presupposed. Were being already and fully fixed, there would be no latitude for sense or determinateness within being, in the way that there would be no latitude for something being determinately left-handed and not right-handed in a perfectly isotropic universe fixed and without room for variation. Sense is possible only if being does not have a fully and already determinate sense. Or better, sense is possible only in virtue of determinacy itself being a sort of openness or exposure oriented by something further. In being determinate, being itself leans and waits upon a broader situation and process. But this is an odd thing to say: what does being itself lean and wait 
upon? What is it that opens a broader situation and process with respect to being itself? In both cases, we would have answer: being. Being leans and waits upon itself as a broader situation and process. We have to say this if we see that the transcendental condition of sense is such that this condition cannot be an already given sense.

This means that the task of phenomenology is studying sense in its concrete manifestation. Most of all, we encounter sense in life as a phenomenon oriented to and by differences that make a difference. So as to not mistakenly impose our own ideas about the origins of sense on things, and to understand how sense has contingently eventuated in our cosmos, our most robust strategy, then, is to study sense as manifest in life, via a phenomenology of life ("zoephenomenology"). This entails a phenomenology of earth ("geophenomenology"), that is, a phenomenology of the cosmological context that grounds and precedes life as phenomenology's radically contingent transcendental condition. Without this we would be prone to the error of conceptualizing life as autonomous sense-constitution. Instead, we need to study life as an institution arising, via passivity, from prior contexts. Zoephenomenology and geophenomenology would enable a robust phenomenology of phenomenology: an empirically anchored phenomenological study of the genesis of sense and phenomenology itself. This study is required to avoid philosophical prejudice or misguided reductions.

Merleau-Ponty's philosophy of tomorrow enjoins us to bring phenomenology down to earth to learn philosophy and how to do philosophy from what precedes us, orients us, and has granted the possibility of philosophy.

\section{References}

Barbaras, Renaud. 1999. Le désir et la distance: Introduction à une phénoménologie de la perception. Paris: J. Vrin. 2003. Vie et intentionalité: Recherches phénoménologiques. Paris: Vrin. 2012. The Phenomenology of Life: Desire as the Being of the Subject. In The Oxford Handbook of Contemporary Phenomenology, edited by D. Zahavi. Oxford: Oxford University Press.

Deacon, Terrence W. 2012. Incomplete Nature: How Mind Emerged from Matter. New York: W.W. Norton.

Fóti, Véronique M. 2013. Tracing Expression in Merleau-Ponty: Aesthetics, Philosophy of Biology, and Ontology. Evanston, IL: Northwestern University Press.

Hass, Lawrence. 2008. Merleau-Ponty's Philosophy. Bloomington: Indiana University Press.

Heidegger, Martin. 1995. The Fundamental Concepts of Metaphysics: World, Finitude, Solitude. Translated by W. McNeill and N. Walker. Bloomington: Indiana University Press.

Jonas, Hans. 1966. The Phenomenon of Life: Toward a Philosophical Biology. Evanston, IL: Northwestern University Press.

Landes, Donald A. 2013. Merleau-Ponty and the Paradoxes of Expression. London: Routledge.

Lawlor, Leonard. 1998. The End of Phenomenology: Expressionism in Deleuze and Merleau-Ponty. Continental Philosophy Review 31:15-34. 
Merleau-Ponty, Maurice. 1942. La structure du comportement. Paris: Quadrige/Presses Universitaires de France.

. 1945. Phénoménologie de la perception. Paris: Gallimard.

-1960. Signes. Paris: Gallimard.

1964. Le visible et l'invisible. Paris: Gallimard.

1989. Le primat de le perception et ses conséquences philosophiques. Grenoble. 2003. L'institution/ la passivité: Notes de cours au Collège de France (19541955). Paris: Editions Belin.

Morris, David. 2004. The Sense of Space. Albany, NY: State University of New York Press.

— 2011. The Chirality of Being: Exploring a Merleau-Ponteian Ontology of Sense. Chiasmi International 12:165-82.

Moss Brender, Noah. 2013. Sense-Making and Symmetry-Breaking: Merleau-Ponty, Cognitive Science, and Dynamic Systems Theory. Symposium: Canadian Journal of Continental Philosophy 17:247-273.

O'Neill, Onora. 2011. Orientation in Thinking: Geographical Problems, Political Solutions. In Reading Kant's Geography, edited by S. Elden and E. Mendieta. Albany: SUNY Press.

Saint Aubert, Emmanuel de. 2006. Vers une ontologie indirecte. Sources et enjeux critiques de l'appel à l'ontologie chez Merleau-Ponty. Paris: Librairie Philosophique Vrin.

Thompson, Evan. 2007. Mind in Life: Biology, Phenomenology, and the Sciences of Mind. Cambridge Mass.: Belknap Press of Harvard University Press.

van Cleve, James, and Robert E. Frederick, eds. 1991. The Philosophy of Right and Left: Incongruent Counterparts and the Nature of Space. Dordrecht: Springer.

Varela, Francisco J. 1991. Organism: A Meshwork of Selfless Selves. In Organism and the Origins of Self, edited by A. I. Tauber. Dordrecht, Netherlands: Kluwer.

Waldenfels, Bernhard. 2000. The Paradox of Expression. In Chiasms: Merleau-Ponty's Notion of Flesh, edited by F. Evans and L. Lawlor. Albany: SUNY Press.

Wirth, Jason M., and Patrick Burke, eds. 2013. The Barbarian Principle: Merleau-Ponty, Schelling, and the Question of Nature. Albany: SUNY Press.

${ }^{1}$ Merleau-Ponty (1989), 43.

${ }^{2}$ Merleau-Ponty (1960), 298.

${ }^{3}$ On sense, see Lawlor (1998), Waldenfels (2000), Landes (2013), Morris (2004), Hass (2008).

${ }^{4}$ Thanks to Randall Johnson for bringing this quote to my attention. Cf. the preface of PhP.

5 Thompson (2007) gives a good way into some of these issues, and is in the background of my discussion. My emphasis on sense pushes the issue in a different direction. Also see Moss Brender (2013) on meaning as symmetry breaking.

${ }^{6}$ This is another way to Merleau-Ponty's point about interior and exterior being in a chiasmatic or reversibility relation. 
${ }^{7}$ Cf. Heidegger (1995) on the lizard as oriented by encircling things. My analysis differs in emphasizing that as self-affected, the organism is implicitly aware of its own orientation, vs. merely being driven by it. This awareness is more explicit in animals being oriented by one another's orientation to food, etc., to the extent of chimps deceiving one another.

${ }^{8}$ Deacon (2012) also tries to show how meaning arises at this level in biological systems, in ways that also involve a sort of incompleteness in being. However, Deacon does not notice how he ultimately conceptualizes incompleteness as a positive deficit in a determinate being — how he needs a more radical ontology.

${ }^{9}$ For this issue in Kant, see van Cleve and Frederick (1991); for more on this in relation to Merleau-Ponty, see Morris (2011).

${ }^{10}$ My topic, argument and strategy here are inspired by Barbaras's focus on phenomenality, even though I take a different path to it, which also leads me to see that in his analysis of biological phenomena, Merleau-Ponty was further ahead than Barbaras allows re. phenomenality.

${ }^{11}$ This is the question that drives Hegel's Science of Logic, a key book for Hyppolite, whose work influence Merleau-Ponty's philosophy and critical appropriation of Hegel. ${ }^{12}$ Heidegger is obviously in the background here, although transformed. On MerleauPonty's relation to Heidegger's ontological difference, see ch. 3 of Saint Aubert (2006). ${ }^{13}$ The question here is not whether these standards are ultimately 'correct'. Rather, the very phenomenon of determinateness, this being $L$ vs. $R$, entails a relation to something beyond that thing, what Peirce calls secondness and thirdness - which I capture in my formula that sense leans and waits upon something further.

${ }^{14}$ Note that being can be determinate in advance of linguistic denominations. E.g., most Earthly life forms can only metabolize proteins that we denominate as left-handed.

Living activity thus enacts a standard that renders being determinate as this and not that. But absent such living, oriented action, determinate being is not manifest.

${ }^{15}$ While Sartre frees nothingness of all determinate content, he puts this determinacy back by conceptualizing nothingness as an activity already prepared to assign determinacy. This is the root of Merleau-Ponty's criticism of Sartre, and why Sartre does not have a philosophy of sense: he roots meaning in cognitive activism, not a passivity of being.

${ }^{16}$ That sense arises through internal inflection is, e.g. behind the note in $V I(316-7)$ on "Chiasm—-Reversibility," which links to the problem of left and right. Put otherwise, the sense of a rhetorical chiasmus arises in circulation across reversed structures; similarly, the sense of being arises in circulation across a reversal internal to being. The sense of being leans and waits upon its own internal reversal, and so determinate being requires what I call development.

${ }^{17}$ The irreducibility of passivity and activity to each other is key to Merleau-Ponty (2003), cf. Morris (2011).

${ }_{18}^{18}$ Barbaras (2012) deduces a similar point from correlation, vs. sense.

${ }^{19}$ See note 16.

${ }^{20}$ The ontological issues here are central to Merleau-Ponty's relation to Schelling and his concept of être sauvage, cf. Wirth and Burke (2013). 